\title{
Comparison of Physical Maps of Ribosomal DNA Repeating Units in Pythium, Phytophthora and Apodachlya
}

\author{
By G. R. KLASSEN,$^{1 *}$ S. A. MCNABB ${ }^{1}$ AND M. W. DICK ${ }^{2}$ \\ ${ }^{1}$ Department of Microbiology, The University of Manitoba, Winnipeg, Manitoba R3T 2N2, \\ Canada \\ ${ }^{2}$ Department of Botany, Plant Science Laboratories, University of Reading, Whiteknights, \\ Reading RG6 2AS, UK
}

(Received 12 January 1987; revised 18 May 1987)

\begin{abstract}
A satellite band in $\mathrm{CsCl}$-bisbenzimide density gradients of Pythium diclinum DNA was found to consist of ribosomal DNA (rDNA) repeating units with a complexity of $10 \cdot 3$ kilobases $(\mathrm{kb})$. Similar satellite bands were also obtained from a morphologically diverse selection of species from the Pythiaceae: Pythium torulosum $(10.4 \mathrm{~kb})$, Pythium irregulare $(11.8 \mathrm{~kb})$, Pythium anandrum $(10.6 \mathrm{~kb})$, Pythium paddicum $(10.6 \mathrm{~kb})$ and Phytophthora cryptogea $(11.2 \mathrm{~kb})$. Physical maps were constructed using seven endonuclease restriction enzymes and the maps were aligned on the basis of nine conserved restriction sites in a $6 \mathrm{~kb}$ region which was shown to be homologous to a DNA plasmid probe containing ribosomal genes from Neurospora crassa. A map of the rDNA region in Apodachlya pyrifera $(10 \cdot 1 \mathrm{~kb})$, a species external to the Pythiaceae (Leptomitales), was also constructed to serve as a taxonomic reference. Percentage sequence divergence values indicated that $P$. diclinum and $P$. torulosum are closely related, but not identical. $P$. anandrum and $P$. irregulare also appeared closely related in spite of morphological differences. $P$. paddicum and Phytophthora cryptogea were the most outlying of the six species of Pythiaceae, but all six species formed a tight cluster when considered against $A$. pyrifera.
\end{abstract}

\section{INTRODUCTION}

Pythium and Phytophthora are two genera in the family Pythiaceae which contain economically important plant pathogens. About 100 species of Pythium, the largest genus of the family, are currently recognized, but they are difficult to identify because of considerable similarity in the morphology of their sexual reproductive structures (Dick et al., 1984). The present study determines taxonomic affinities by comparing endonuclease restriction maps of ribosomal DNA (rDNA) sequences. This approach is feasible because Pythium and Phytophthora species have a prominent satellite band in $\mathrm{CsCl}$-bisbenzimide gradients that consists of rDNA repeating units, as reported in this study.

The selection of a small group of Pythium species for comparison of rDNA restriction sites was based on sporangial morphology and sporangial renewal, traits which show the most striking differences within the genus. Pythium diclinum and Pythium torulosum both have a more or less filamentous sporangium, although that of $P$. diclinum is strictly filamentous though sometimes branched, while that of $P$. torulosum is contorted into distinctive toruloid swellings. Pythium irregulare seldom produces sporangia, but when they are formed they are small (about $1750 \mu \mathrm{m}^{3}$ ), spherical, and terminal or intercalary. Pythium anandrum produces large (about $47500 \mu \mathrm{m}^{3}$ ) ellipsoid sporangia that sometimes show internal renewal, and has spiny oogonia. Pythium paddicum has sporangia of intermediate dimensions and has papillate oogonia. Thus, the five species can be regarded as spanning the range of sporangial diversity within the genus.

Abbreviation: rDNA, ribosomal DNA. 
A well-known species of Phytophthora, P. cryptogea, was selected as an outgroup for the genus Pythium and Apodachlya pyrifera (Leptomitales) was selected as an outgroup for the Pythiaceae within the Pythiales.

\section{METHODS}

Species. Pythium diclinum (4110a), Pythium anandrum (4401d), Pythium torulosum (4212b), Phytophthora cryptogea (JM10) and Apodachlya pyrifera (502a) were provided by M. W. Dick from the Aquatic Phycomycete Culture Collection, University of Reading, UK; Pythium irregulare (174) was obtained from D. J. S. Barr (Biosystematics Research Institute, Ottawa, Canada); Escherichia coli C600SF8 carrying the plasmid pMF2 was a gift from Robert L. Metzenberg (Department of Physiological Chemistry, University of Wisconsin, Madison, Wisconsin, USA). pMF2 was derived from pBR 322 and contains a $6.5 \mathrm{~kb}$ insert from the Neurospora crassa rDNA repeat unit in the ampicillin resistance gene. The $17 \mathrm{~S}, 5.8 \mathrm{~S}$ and $26 \mathrm{~S}$ rRNA coding regions are fully represented in pMF2 (Free et al., 1979).

Growth of cultures. From stock axenic cultures (Clark \& Dick, 1974; Dick, 1965) an agar plug was transferred to a Petri plate containing V8 broth $(2.5 \%, \mathrm{v} / \mathrm{v}, \mathrm{V} 8$ juice), and allowed to grow at room temperature into a thick mycelial mat. The mat was transferred to $500 \mathrm{ml} \mathrm{V} 8$ broth in a 1 litre flask, shaken vigorously and the contents dispensed into Petri plates. Cultures were allowed to grow into thick mats. Six mats were used to inoculate 21 baffle flasks containing $500 \mathrm{ml}$ PYG medium (Griffin et al., 1974) which were shaken vigorously at room temperature for 3-5d. Mycelium was harvested by vacuum filtration through Whatman no. 1 filter paper. The mycelial mat was rinsed thoroughly with distilled water and then with isolation medium $(0.35 \mathrm{M}$-sucrose, $50 \mathrm{mM}$ EDTA, $10 \mathrm{~mm}$-Tris/ $\mathrm{HCl}$ buffer, $\mathrm{pH} 7 \cdot 4$ ). The mycelium was stored at $-40{ }^{\circ} \mathrm{C}$ when not used immediately.

Isolation of DNA. Frozen or fresh mycelial mats were broken into small pieces with a mortar and pestle and then blended in liquid nitrogen. Generally $20-40 \mathrm{~g}$ of frozen mycelium were ground for a typical isolation. DNA was prepared by phenol extraction and $\mathrm{CsCl}$-bisbenzimide density centrifugation as described by Garber \& Yoder (1983).

DNA digestion and electrophoresis. Restriction enzymes were obtained from Boehringer Mannheim or BRL and used according to manufacturers' instructions. Electrophoresis was done in TBE buffer (0.089 M-Tris, $0.089 \mathrm{M}$ boric acid, $2.5 \mathrm{~mm}$-EDTA) using $0.8 \%, 1.0 \%$, or $1.2 \%(\mathrm{w} / \mathrm{v})$ agarose submarine gels. The BRL $1 \mathrm{~kb}$ ladder was used as a standard for determining fragment size. Gels were stained for $20 \mathrm{~min}$ in $0.5 \mu \mathrm{g}$ ethidium bromide $\mathrm{ml}^{-1}$ and viewed under UV light.

Hybridizations. pMF2 plasmid DNA was prepared from E. coli C600SF8 (Free et al., 1979) using the preparative method of Birnboim \& Doly (1979). Plasmid DNA was nick-translated according to the method of Rigby et al. (1977). Southern blots were prepared using Gene Screen Plus (New England Nuclear) according to the manufacturer's instructions. Prehybridization was done at $55^{\circ} \mathrm{C}$ by agitating the membrane for $6 \mathrm{~h}$ in prehybridization fluid ( $1 \% \mathrm{SDS}, 1 \mathrm{M}$-sodium chloride). The probe was denatured, added to the prehybridization fluid and incubated at $55^{\circ} \mathrm{C}$ with constant agitation for $16-24 \mathrm{~h}$. After hybridization the filters were washed twice in $2 \times$ SSC (SSC: $0.15 \mathrm{M}$-sodium chloride, $0.015 \mathrm{M}$-sodium citrate, $\mathrm{pH} 7.0$ ) at room temperature for $10 \mathrm{~min}$ each, then twice in $2 \times \mathrm{SSC}$ and $1 \% \mathrm{SDS}$ at $55^{\circ} \mathrm{C}$ with constant agitation for $30 \mathrm{~min}$. Autoradiography was done for 24$48 \mathrm{~h}$ at $-70^{\circ} \mathrm{C}$.

Restriction mapping of the rDNA repeat unit. Mapping of DNA was done by analysis of single and double restriction enzyme digestions of DNA preparations containing the rDNA repeating unit. For Phytophthora cryptogea, which did not produce a well-resolved middle band on the $\mathrm{CsCl}$ density gradient, the chromosomal band, which was highly enriched in rDNA, was used as the source of rDNA. To map the $A$.pyrifera rDNA unit, bands were visualized by hybridization to the $N$. crassa rDNA probe pMF2, since restriction of chromosomal DNA did not yield clearly visible bands after ethidium bromide staining.

\section{RESULTS AND DISCUSSION \\ rDNA satellite bands}

When DNA from Pythium diclinum was isolated on a $\mathrm{CsCl}$-bisbenzimide density gradient, three bands were visible under UV light (Fig. 1a). The top and bottom bands fluoresced blue while the middle band fluoresced green. This separation and colour pattern has been observed for all species of Pythium studied to date. The same band pattern was found with Phytophthora cryptogea DNA but with much less resolution of the middle and bottom bands. Apodachlya pyrifera DNA produced two sharp blue bands, well resolved from each other.

The width and intensity of each band on the gradient varied between different species and even between different preparations of the same species. In general the middle band was the broadest and most intense, but the relative amount of DNA recovered from each band could not 
(a)

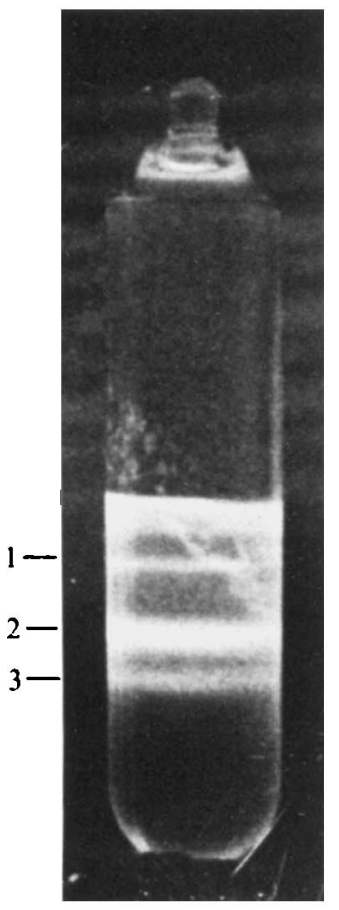

(b)

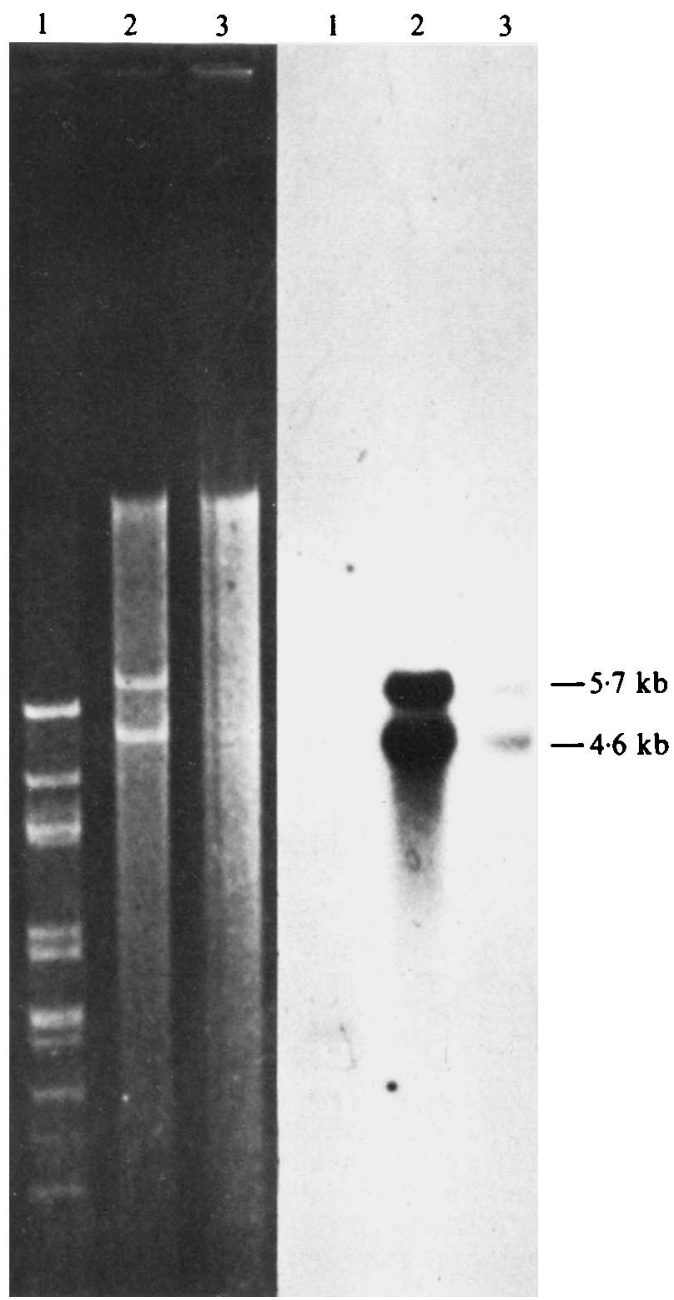

Fig. 1. Identification of rDNA in $P$. diclinum. (a) $\mathrm{CsCl}$-bisbenzimide density gradient of $P$. diclinum DNA. (b) HindIII digestion of DNA from bands shown in $(a)$. Lane 1, top band; lane 2, middle band; lane 3, bottom band. (c) Hybridization of pMF2 to the profiles in $(b)$. Size estimations were based on the BRL $1 \mathrm{~kb}$ ladder.

be predicted from these appearances. The colour differences and lack of linearity between fluorescence and DNA concentration in bands may be due to spectral shifts occurring when bisbenzimide binds to DNA molecules of varying AT composition (Muller \& Gautier, 1975).

DNA recovered from the three bands shown in Fig. 1(a) was digested with HindIII and the fragments separated by agarose gel electrophoresis (Fig. 1b). DNA from the top band produced a pattern typical of mitochondrial DNA (G. R. Klassen, unpublished results). DNA from the bottom band appeared to be of high complexity, producing no discernible restriction bands, and thus was presumed to be chromosomal DNA. Most of the DNA in the middle band was digested to form bands of $5 \cdot 7$ and $4.6 \mathrm{~kb}$, indicating low sequence complexity.

Similar satellite bands have been described for other fungi and have in several cases been found to consist of rDNA repeating units (Garber \& Yoder, 1983; Raeder \& Broda, 1984; Specht et al., 1984). To determine whether this was the case for Pythium diclinum, the gel 

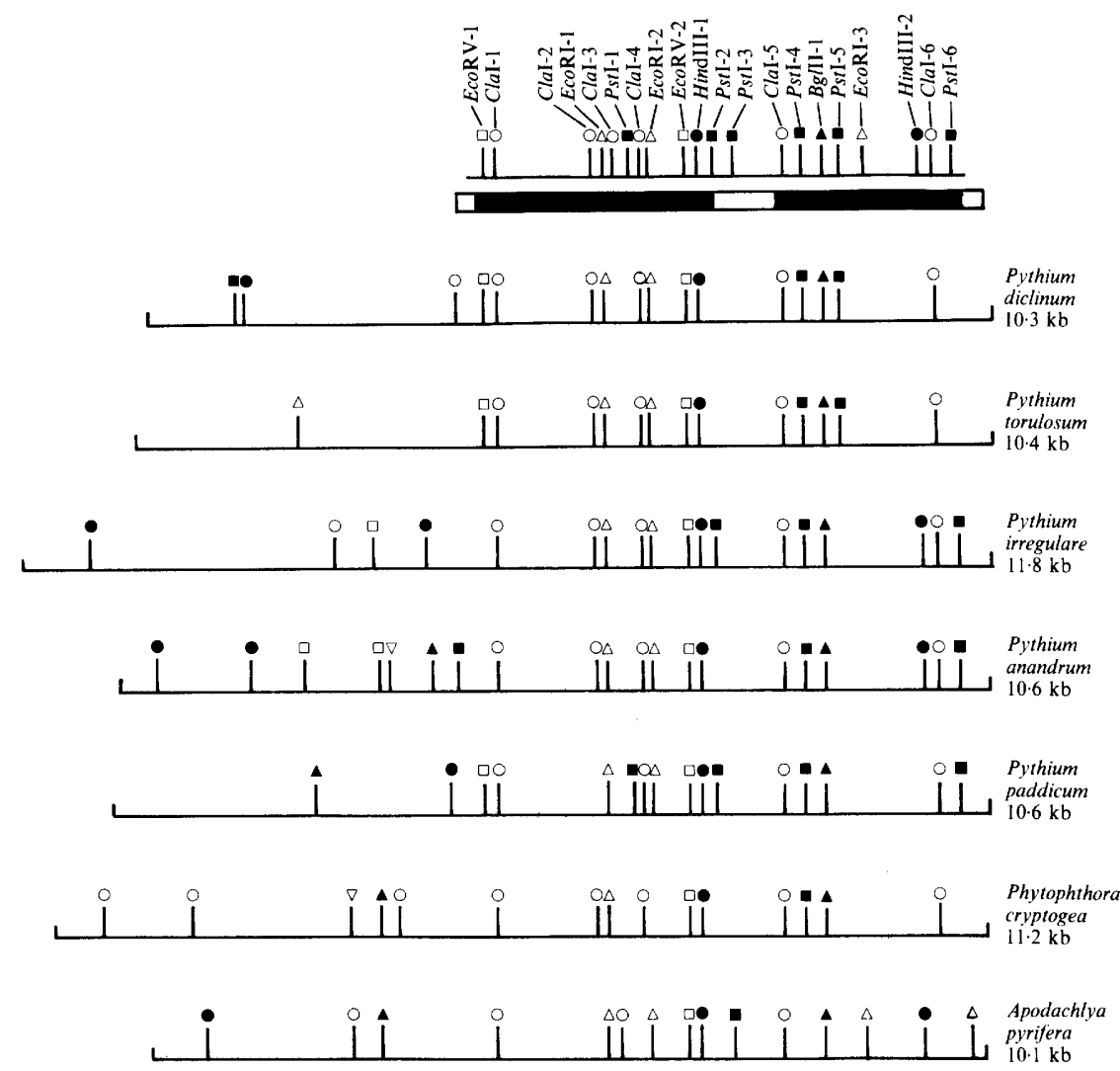

$1 \mathrm{~kb}$

Fig. 2. Restriction maps of the rDNA repeating units from seven oomycetes. The twenty sites compared are listed in sequence on the top bar. Map regions hybridizing strongly to pMF 2 are indicated by the solid parts of the bar; regions with weak or no hybridization are shown by the open part of the bar. The restriction sites are indicated by the following symbols: $\square, E c o R V ; O, C l a \mathrm{I} ; \triangle, E c o$ RI; $\square$, Pst I ๑ HindIII $\boldsymbol{\Delta}, B g l \mathrm{II} ; \nabla, B a m \mathrm{HI}$. The presence of these restriction sites and the relative lengths of the repeating units are shown below for each species. The $6 \mathrm{~kb}$ section analysed further in Figs 3 and 4 is that to the right of the diagram between EcoRV-1 and Pst I-6, both inclusive.

(Fig. $1 b$ ) was blotted and the DNA probed with pMF2. The results (Fig. $1 c$ ) indicated that nearly all of the DNA of $P$. diclinum homologous to $N$. crassa rDNA was located in the 5.7 and $4.6 \mathrm{~kb}$ HindIII fragments derived from the middle $\mathrm{CsCl}$ band. Faint hybridization to the bottom band DNA at 5.7 and $4.6 \mathrm{~kb}$ indicated either that the bottom band was contaminated with middle band DNA or that a small fraction of the rDNA remained associated with chromosomal DNA. The middle band in Pythium species is far more prominent than corresponding bands from other fungi (Garber \& Yoder, 1983).

Middle band DNA from $P$. diclinum was digested with six more restriction enzymes and in each case the size of the repeating unit of the DNA was found to be $10 \cdot 3 \mathrm{~kb}$. A restriction map of the sequence (Fig. 2) indicates that discrete termini do not exist, and thus that the molecule is either circular or consists of a number of tandem repeating segments. The DNA was partially digested with $B g l$ II, which cuts the sequence only once, and a ladder of approximately 10,20 and $30 \mathrm{~kb}$ bands was discernible on a $0.4 \%$ agarose gel (data not shown). This indicates that at least three tandem repeats exist, either in a linear array or as a circular molecule.

Gels containing the DNA fragments from Pythium diclinum that had been used for the construction of the map of middle band DNA were blotted and probed with pMF2 in order to 


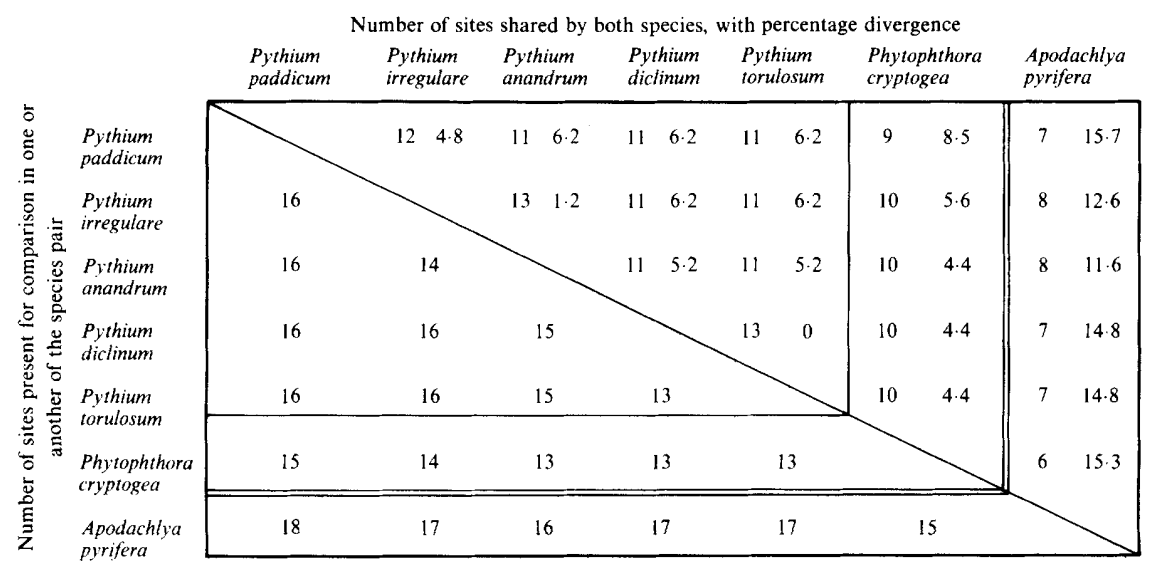

Fig. 3. Matrix to show restriction enzyme sequence divergence between each pair of species for the $6 \mathrm{~kb}$ region of the rDNA repeating units depicted in Fig. 2. Percentage sequence divergence was calculated using the formula (Brown et al., 1979)

$$
\begin{aligned}
& -100 \ln S / N \\
& \text { where } \\
& \text { and } \\
& \begin{array}{l}
\text { number of sites present in both species } \\
\text { number of nucleotides recognized }=N=6
\end{array}=S
\end{aligned}
$$

(BamHI did not restrict within the $6 \mathrm{~kb}$ region, cf. Fig. 2.)

localize the ribosomal genes on the map. As shown in Fig. 2, a region of $6 \mathrm{~kb}$ showed strong homology to the probe. The homologous region was interrupted by a short $(0.5-1.0 \mathrm{~kb})$ region of heterology which divided the homologous region into long $(3 \cdot 0-3.5 \mathrm{~kb})$ and short $(2.5 \mathrm{~kb})$ segments. Further studies are in progress to define the ribosomal genes within these regions.

\section{rDNA physical maps}

Physical maps of middle band DNA from Pythium diclinum, $P$. torulosum, $P$. irregulare, $P$. anandrum, $P$. paddicum and Phytophthora cryptogea were constructed and aligned on the basis of nine conserved restriction sites, all within the region shown to be homologous to $N$. crassa ribosomal genes (Fig. 2). The $A$. pyrifera map was constructed by restriction of chromosomal DNA and hybridization to the $N$. crassa probe. It was easily aligned with the other maps because six of the nine sites conserved in Pythium and Phytophthora were also conserved in Apodachlya. The regions of the repeating units not hybridizing to $N$. crassa ribosomal genes could not be aligned due to lack of a sufficient number of restriction sites and due to presumed insertions and deletions which are reflected in the differences in length of the repeating units.

The size of the rDNA repeating unit in the oomycetes investigated ranged from $10 \cdot 1 \mathrm{~kb}(A$. pyrifera) to $11.75 \mathrm{~kb}(P$. irregulare $)$, with an average of $10.7 \mathrm{~kb}$. This is slightly larger than typical sizes reported for basidiomycetes $(9 \cdot 2-10 \mathrm{~kb})$ (Raeder \& Broda, 1984; Specht et al., 1984) and for ascomycetes (7.7-11.1 kb) (Bell et al., 1977; Lockington et al., 1982; Russell et al., 1984; Verbeet et al., 1984).

\section{Taxonomic analysis}

Quantitative comparisons of the physical maps were based only on the $6 \mathrm{~kb}$ region which could be easily aligned (Fig. 2). The map positions of the twenty points scored for the presence or absence of restriction sites are given at the top of Fig. 2. In only one case is the interpretation dubious - the ClaI-3 site in A. pyrifera may in fact be the ClaI-4 site conserved in the other species. The effect of this alternative interpretation of the data is that the average percentage divergence of $A$. pyrifera is reduced from $14.1 \%$ to $11.9 \%$. Since both values are substantially higher than values within the Pythium-Phytophthora group (Fig. 3) this alternate scoring of ClaI sites does not affect conclusions drawn from the data. 


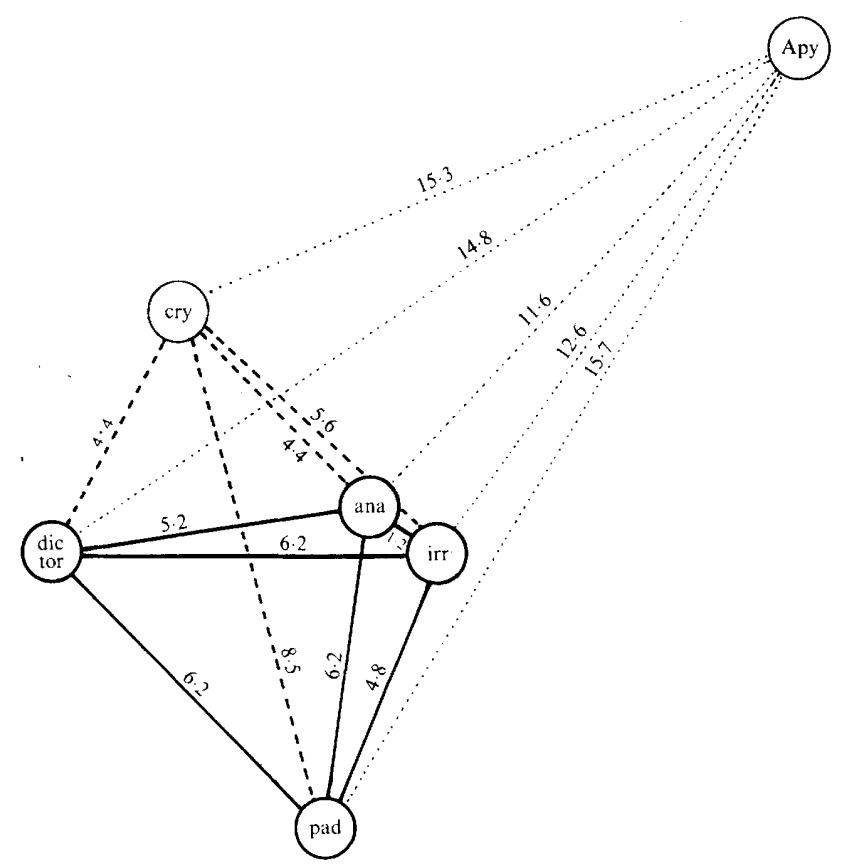

Fig. 4. Multidimensional diagram, based upon data in Fig. 3, to show relationships between percentage sequence divergences of the $6 \mathrm{~kb}$ region of the rDNA repeating units. Divergences within the Pythiaceae are drawn to scale. Symbols: dic, Pythium diclinum; tor, P. torulosum; ana, P. anandrum; irr, $P$. irregulare; pad, P. paddicum; cry, Phytophthora cryptogea; Apy, Apodachlya pyrifera. Divergences for Apodachlya are not to scale. Note the relative distances of Phytophthora cryptogea and Pythium paddicum with respect to the other Pythium species.

Morphological criteria (M. W. Dick, unpublished) suggest that there are perhaps five major centres of speciation within Pythium. $P$. anandrum, $P$. torulosum $/ P$. diclinum and $P$. irregulare correspond to three of these groups. Molecular divergence data can be used to begin to test this suggestion. $P$. diclinum and $P$. torulosum showed no divergence in the region of rDNA being compared but differed in the remaining part of the repeating unit and differed slightly in the size of the repeating unit (Fig. 2). This suggests that the two species are distinct but quite closely related. If this conclusion is accepted, then the difference in appearance of sporangia caused by toruloid swelling is of slight taxonomic importance.

At a number of points more significant discrepancies appear between molecular and morphological criteria. The low percentage divergence between $P$. anandrum and $P$. irregulare is not consistent with major morphological differences in the size and shape of sporangia. Also, the fact that $P$. anandrum and $P$. paddicum both have ornamented oogonia was not reflected in a lower percentage divergence between the two species. The latter phenomenon suggests that this criterion may have relevance only to species delimitation within the major sections of the genus, as is the case with the Achlya racemosa group of the Saprolegniaceae (Dick, 1973) in another subclass of the Oomycetes. In addition, $P$. paddicum showed the highest percentage divergence from both Phytophthora and Apodachlya and was also an outlier species within the genus Pythium in spite of its intermediate spherical sporangia.

The relationship between Phytophthora and the Pythium group was striking. The percentage divergences (Fig. 3) of Phytophthora cryptogea, Pythium paddicum, $P$. anandrum and P. irregulare are all greater than those for $P$. torulosum and $P$. diclinum. This suggests that there are divergences in different directions as shown in Fig. 4. The degrees of divergence are comparable between the various species of Pythium and Phytophthora but not for the other outgroup, Apodachlya. Taxonomically, this could be taken as providing a prima facie case for examining 
the generic boundaries within the Pythiaceae and for considering a subdivision of Pythium. Such a step must not be undertaken lightly because the type species of the genus, $P$. monospermum, belongs, on morphological evidence, to the $P$. torulosum $-P$. diclinum group. None of the common pathogens belongs to this group so nomenclatural changes would have severe repercussions.

A more comprehensive survey is required to determine whether the differences reported here are merely part of a continuum or whether there are identifiable discontinuities which correlate between biochemical and morphological data. The accessibility of oomycete rDNA repeating units due to the prominent satellite bands in $\mathrm{CsCl}$-bisbenzimide gradients will make it more feasible to use molecular criteria to resolve taxonomic problems in the future.

This work was initiated as the result of research study leave granted to G. R.K. by the University of Manitoba and was supported by operating and travel grants provided by the Natural Sciences and Engineering Research Council of Canada. We are also indebted to Robert Metzenberg for the gift of the plasmid pMF2. We thank Abbes Belkhiri and Gillian Clark in Reading and David Boyd, Michael Bryan and Carla Chrusch in Winnipeg for laboratory assistance.

\section{REFERENCES}

Bell, G. I, DeGennaro, L. J., Gelfand, D. H., Bishop, R. J., Valenzuela, P. \& Rutter, J. R. (1977). Ribosomal RNA genes of Saccharomyces cerevisiae. Journal of Biological Chemistry 252, 81188125.

Birnboim, H. C. \& Doly, J. (1979). A rapid alkaline extraction procedure for screening recombinant plasmid DNA. Nucleic Acids Research 7, 1515-1523.

Brown, W. M., George, M., JR \& Wilson, A. C. (1979). Rapid evolution of animal mitochondrial DNA. Proceedings of the National Academy of Sciences of the United States of America 76, 19671971.

Clark, G. \& Dick, M. W. (1974). Long-term storage and viability of aquatic Oomycetes. Transactions of the British Mycological Society 63, 611-612.

Dick, M. W. (1965). The maintenance of stock cultures of Saprolegniaceae. Mycologia 57, 828-829.

Dick, M. W. (1973). Saprolegniales. In The Fungi, an Advanced Treatise, pp.113-144. Edited by G. C. Ainsworth, F. K. Sparrow \& A. L. Sussman. New York: Academic Press.

Dick, M. W., Wong, P. T. W. \& Clark, G. (1984). The identity of the oomycete causing 'Kikuyu Yellows', with a reclassification of the downy mildews. Botanical Journal of the Linnean Society 89, 171-197.

Free, S. J., Rice, P. W. \& Metzenberg, R. L. (1979). Arrangement of the genes coding for ribosomal ribonucleic acids in Neurospora crassa. Journal of Bacteriology 137, 1219-1226.

Garber, R. C. \& Yoder, O. C. (1983). Isolation of DNA from filamentous fungi and separation into nuclear, mitochondrial, ribosomal, and plasmid components. Analytical Biochemistry 135, 416-422.

Griffin, D. H., Timberlake, W. E. \& Cheney, H. C. (1974). Regulation of macromolecular synthesis, colony development, and specific growth rate of Achlya bisexualis during balanced growth. Journal of General Microbiology 80, 381-388.

Lockington, R. A., Taylor, G. G., Winther, M., Scazzochio, C. \& Davies, R. W. (1982). A physical map of the ribosomal DNA repeat unit of Aspergillus nidulans. Gene 20, 135-137.

Muller, W. \& Gautier, F. (1975). Interactions of heteroaromatic compounds with nucleic acids. European Journal of Biochemistry 54, 385-394.

RAEDER, U. \& BRODA, P. (1984). Comparison of the lignin-degrading white rot fungi Phanerochaete chrysosporium and Sporotrichum pulverulentum at the DNA level. Current Genetics 8, 499-506.

Rigby, P. W. J., Dieckmann, M., Rhodes, C. \& Berg, P. (1977). Labelling deoxyribonucleic acid to high specific activity in vitro by nick translation with DNA polymerase I. Journal of Molecular Biology 113, 237-251

Russell, P. J., Wagner, S., Rodland, K. D., Feinbaum, R. L., Russell, J. P., Bret-Harte, M. S., Free, S. J. \& MetzenberG, R. L. (1984). Organization of the ribosomal ribonucleic acid genes in various wild-type strains and wild-collected strains of Neurospora. Molecular and General Genetics 196, 275-282.

Specht, C. A., Novotmy, C. P. \& Ullrich, R. C. (1984). Strain specific differences in ribosomal DNA from the fungus Schizophyllum commune. Current Genetics 8, 219-222.

Verbeet, M. Ph., van Heerikhuizen, H., Klootiwisk, J., FontiJn, R. D. \& Planta, R. J. (1984). Evolution of yeast ribosomal DNA: molecular cloning of the rDNA units of Kluyveromyces lactis and Hansenula wingei and their comparison with the rDNA units of other Saccharomycetoideae. Molecular and General Genetics 198, 116-125. 